\title{
ANALISIS TINGKAT PAPARAN RADIASI DI AREA SETINGGI MATA DOKTER OPERATOR SELAMA PEMERIKSAAN DIAGNOSTIK CORONARY ANGIOGRAPHY DI RUANG CATHLAB
}

\author{
${ }^{1}$ Devi Aprilia Primaningtyas, ${ }^{2}$ Soegardo Indra Praptono, ${ }^{3}$ Lailatul Muqmiroh \\ 1,2,3 Program Studi D-IV Radiologi Fakultas Vokasi Universitas Airlangga
}

\begin{abstract}
Background : The radiation exposure of interventional cardiology can provide biological effects on patients and workers that is deterministic and stochastic effects. One organ that accepts the possibility of deterministic effects are the eyes. To find out the possibility of cataracts is measuring the level of radiation exposure in the area of radiation workers at eye level during the diagnostic coronary angiography procedures.
\end{abstract}

Method: the measurement of the level of radiation exposure in the area of physician eye-level using a survey meter directly at the physician position. Measurements were made on the variation of the projection during diagnostic coronary angiography examination including PA-Cranial, LAOCranial, LAO-Caudal, RAO-Cranial, RAO-Caudal, RAO and LAO.

Result: Measuring the level of radiation exposure in the area at physician eye-level during diagnostic coronary angiography obtained on sample A of $15.34 \mu \mathrm{Sv}$ for 69.17 seconds (1 minute 9.17 seconds and sample B of $25.11 \mu \mathrm{Sv}$ for 46 seconds. The total dose, DAP (dose Area Product) and fluoroscopy time of the operator A is higher than the operator B.

Conclusion: The level of radiation exposure in the area of physician eye-level during diagnostic coronary angiography examination obtained does not exceed the dose limit value (NBD) is $75 \mu \mathrm{Sv}$ h.

Keywords : exposure, exposure level, radiation exposure, radiation of the eye, radiation intervention.

\section{Pendahuluan}

Pemanfaatan kardiologi intervensional saat ini sudah semakin luas, hal ini ditunjukkan dengan banyaknya rumah sakit yang sudah memiliki fasilitas Cathlab. Pada Laboratorium Jantung di Hospital Clinico-Chile, petugas dalam laboratorium tersebut terdiri dari 5 dokter kardiologi, 2 perawat, 2 teknisi kesehatan dan 5 asisten lainnya melakukan pemeriksaan diagnostik coronary arteriograms sejumlah 1300 pasien dan 350 pasien dengan pemeriksaan PTCA (Percutaneus Transluminal Coronary Angioplasty) setiap tahunnya (IAEA), 2009).

Dosis radiasi pada kardiologi intervensional jauh lebih besar daripada x-ray konvensional. Zonghua (2013) menyatakan bahwa prosedur kardiologi intervensional memberikan paparanradiasi medis hanya $12 \%$ dari seluruh pemeriksaan radiologi, namun radiasinya tertinggi hingga $50 \%$ dari total dosis efektif kolektif, yaitu berjumlah setara dengan 160 pemeriksaan foto thorax per kepala tiap tahun di AS. Dosis radiasi pada pemeriksaan coronary angiography setara 1000 kali pemeriksaan foto thorax (Renato, dkk;2007).Paparan radiasi dapat memberikan efek biologis pada pasien dan pekerja. Ada dua efek biologis akibat radiasi yaitu efek stokastik (terjadi kanker dan efek genetik) dan efek deterministik yang dapat dilihat dan diprediksi secara langsung perubahan pada jaringan lunak (Zonghua;2013). Efek deterministik yang bisa terjadi antara lain kerusakan kulit, eritema, epilepsi, katarak (BATAN;2011).

Berkaitan dengan efek paparan radiasi, pekerja radiasi perlu melaksanakan pedoman proteksi radiasi selama melaksanakan prosedur pemeriksaan intervensional kardiologi tersebut. Tiga hal yang perlu diingat dalam pedoman proteksi radiasi yaitu jarak, waktu, dan peralatan pelindung (shielding). Berdasarkan 
PERKA BAPETEN Nomor 8 Tahun 2011 pasal 35 ayat (6) menjelaskan bahwa peralatan proteksi radiasi sebagaimana dimaksud pada ayat huruf $b$ meliputi; apron, tabir dilapisi $\mathrm{Pb}$ dan kaca $\mathrm{Pb}$, kacamata $\mathrm{Pb}$, sarung tangan $\mathrm{Pb}$, pelindung thyroid $\mathrm{Pb}$, pelindung ovarium dan/atau pelindung gonad.

Salah satu organ yang menerima kemungkinan efek deterministik adalah mata. Organ mata merupakan organ yang paling sensitif terhadap radiasi. Bahaya paparan radiasi berlebihan pada mata dapat mengakibatkan kerusakan pada lensa mata yang lama kelamaan dapat menyebabkan kebutaan akibat katarak. Nilai Batas Dosis (NBD) menurut PERKA BAPETEN Nomor 8 Tahun 2011 pasal 30 ayat 3 huruf a menyatakan bahwa untuk pekerja radiasi tidak boleh melampaui dosis ekuivalen pada lensa mata sebesar $150 \mathrm{mSv}$ dalam satu tahun. Untuk mengetahui kemungkinan katarak tersebut adalah melakukan pengukuran dosis area setinggi mata pekerja radiasi dengan menggunakan alat ukurradiasi.

\section{Metode}

Penelitianini menggunakan desain penelitian Deskriptif Observasional. Peneliti mengukur tingkat paparan radiasi di area setinggi mata dokter operator menggunakan survey meter Thermo Scientific seri FH 40 G-L dalam berbagai sudut proyeksi serta mencatat waktu yang diperlukan setiap proyeksi. Sampel sumber data yang digunakan adalah tingkat paparan radiasi di area setinggi mata dokter operator pada tindakan diagnostik Coronary Angiography. Peneliti mencatat kv, mA, fluoroscopy time, DAP (Dose Area Product) yang digunakan selama pemeriksaan dari awal hingga akhir. Pengukuran dilakukan pada beberapa proyeksiseperti PA-Cranial $30^{\circ}$, LAO $45^{\circ}$, LAO $30^{\circ}$-Cranial $20^{\circ}$, LAO $50^{\circ}$-Caudal $20^{\circ}$, RAO $30^{\circ}$-Cranial $20^{\circ}$, RAO $30^{\circ}$-Caudal $20^{\circ}$, RAO (gambar 1), dan diperoleh data pengukuran tingkat paparan radiasi di area setinggi mata dokter operator yang dianggap dosis ekivalen pada mata. Pengukuran tingkat paparan radiasi di area setinggi mata dokter operator dilakukan sesuai dengan skema pengukuran yang ditunjukkan pada Gambar 2.

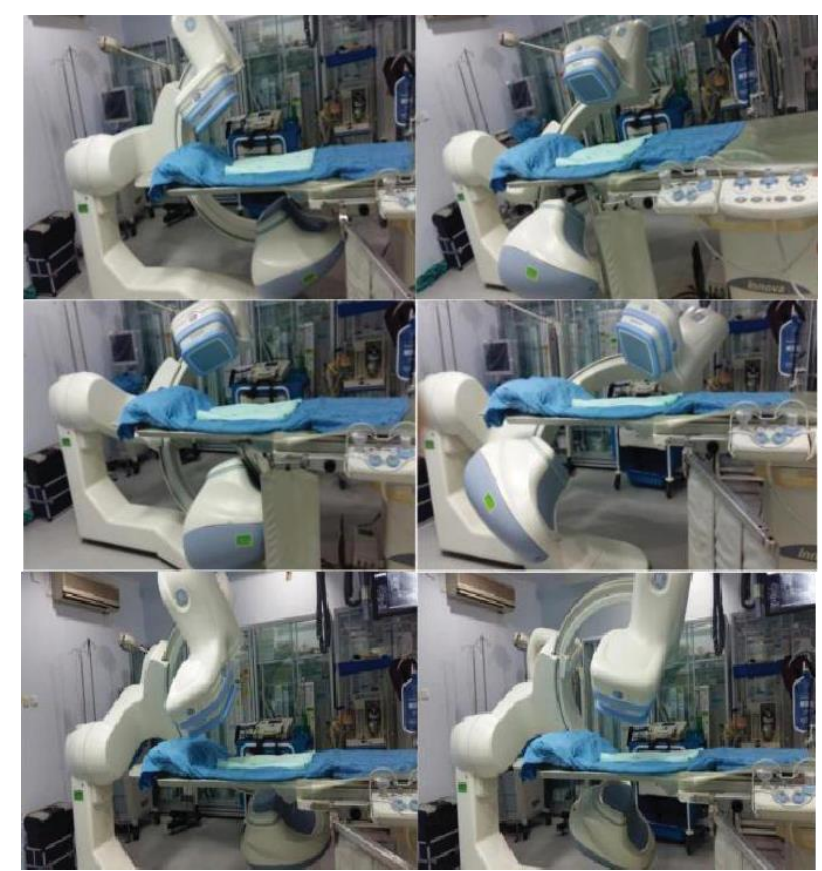

Gambar 1. Beberapa proyeksi yang digunakan dalam pengukuran dosis. a.Posisi PA cranial $30^{\circ}$, b. Posisi LAO $45^{\circ}$ c. Proyeksi LAO $30^{\circ}$-Cra $20^{\circ}$ d. Proyeksi LAO $50^{\circ}$-Cau $20^{\circ}$ e. Proyeksi RAO $30^{\circ}$ - Cra $20^{\circ} \mathrm{f}$. Proyeksi RAO $30^{\circ}$-Cau $20^{\circ}$

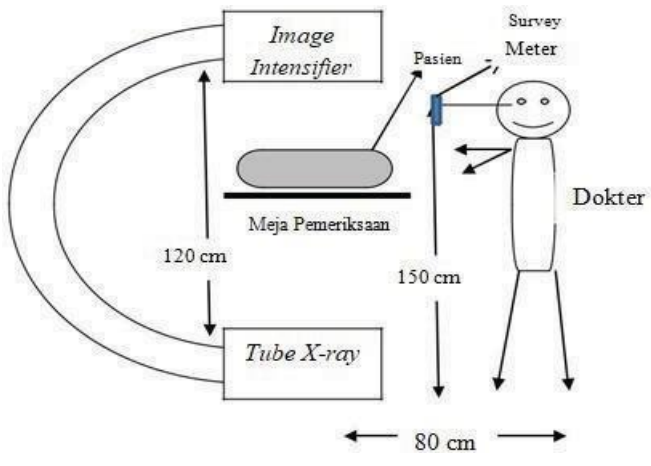

Gambar 2. Skema pengukuran dosis area setinggi mata dokter operator.

\section{Hasil dan Pebahasan}

\section{Faktor eksposi}

Pada alat fluoroskopi di ruang cathlab menggunakan Automatic Exposure Control (AEC) menyebabkan nilai $\mathrm{kV}$ dan $\mathrm{mA}$ menjadi tidak tetap. Nilai $\mathrm{kV}$ dan $\mathrm{mA}$ selama pemeriksaan diagnostik coronary angiography ditunjukkan pada Tabel 1.

Tabel 1: Rentang nilai $\mathrm{kV}$ dan $\mathrm{mA}$ pada alat fluoroskopi di Ruang Cathlab

\begin{tabular}{|lcccc|}
\hline & Max & Min & Rata-rata & Median \\
\hline $\mathrm{kV}$ & 120 & 80 & 91,2 & 90 \\
$\mathrm{~mA}$ & 20 & 12 & 16,8 & 18 \\
\hline
\end{tabular}


Penggunaan $\mathrm{kV}$ maksimal selama pemeriksaan diagnostic coronary angiography adalah 120 dan $\mathrm{kV}$ minimal adalah 80 . Kuat arus (mA) maksimal yang digunakan yaitu 20 dan $\mathrm{mA}$ minimal yaitu 12 . Field of View (FOV) yang digunakan selama pemeriksaan adalah $17 \mathrm{~cm}$ dengan penggunaan fluoroscopy pulse 15 frame per second.

\section{Pengukuran Tingkat Paparan Radiasi di Area setinggi Mata Dokter Operator pada setiap Proyeksi selama Pemeriksaan Diagnostic Coronary Angiography}

Pengukuran tingkat paparan radiasi di area setinggi mata dokter operator atas dua pasien selama pemeriksaan diagnostic coronary angiography di ruang cathlab pada bulan Juni 2016. Hasil data pengukuran tingkat paparan radiasi di area setinggi mata dokter operator ini kemudian data pengukuran tersebut dikalikan dengan faktor kalibrasi alat ukur yaitu 1,15 dan didapatkan dosis area setinggi mata dengan dikalikan oleh waktu fluoroskopi digunakan. Adapun hasil pengukuran tingkat paparan radiasi di area setinggi mata ditunjukkan pada Tabel 2 dan Tabel 3.

Pada Tabel 2 menunjukkan tingkat paparan radiasi di area setinggi mata yang terukur dengan alat ukur survey meter pada pasien A dengan operator B pada setiap proyeksi yang dilakukan memberikan total laju tingkat paparan radiasi sebesar $5490 \mu \mathrm{Sv} / \mathrm{h}$ dengan tingkat paparan radiasi di area setinggi mata diperoleh sebesar 15,34 $\mu \mathrm{Sv}$ selama 69,17 detik (1menit 9,17 detik).

Tabel 2: Hasil Pengukuran dosis area setinggi mata dokter operator pada pasien A.

\begin{tabular}{|c|c|c|c|c|c|c|c|}
\hline \multirow[t]{2}{*}{ No } & \multirow[t]{2}{*}{$\begin{array}{l}\text { Proyeksi dan } \\
\text { sudut }\end{array}$} & \multicolumn{2}{|c|}{$\begin{array}{l}\text { Faktor } \\
\text { eksposi }\end{array}$} & $\begin{array}{c}\text { Laju } \\
\text { tingkat } \\
\text { paparan } \\
\text { radiasi } \\
\text { setinggi } \\
\text { mata }\end{array}$ & Waktu & \multirow[t]{2}{*}{$\begin{array}{c}\text { Tingkat } \\
\text { paparan } \\
\text { radiasi di } \\
\text { area } \\
\text { setinggi } \\
\text { mata } \\
\mu \mathrm{Sv} \\
\end{array}$} & \multirow[t]{2}{*}{ Frame } \\
\hline & & $\mathrm{kV}$ & $\mathrm{mA}$ & $\mu \mathrm{S} v \mathrm{~h}$ & Detik & & \\
\hline & $\operatorname{PACRA} 30^{\circ}$ & 80 & 19 & 791 & 12,4 & 2,72 & 186 \\
\hline & $\operatorname{RAO} 29^{\circ} \mathrm{CRA} 19^{\circ}$ & 80 & 18 & 645 & 8,8 & 1,58 & 132 \\
\hline & RAO $29^{\circ} \mathrm{CAU} 19^{\circ}$ & 80 & 18 & 1003 & 9,93 & 2,77 & 149 \\
\hline & $\mathrm{LAO} 29^{\circ} \mathrm{CRA} 21^{\circ}$ & 90 & 19 & 645 & 8,86 & 1,59 & 133 \\
\hline & LAO $52^{\circ} \mathrm{CAU} 29^{\circ}$ & 120 & 12 & 589 & 8,06 & 1,32 & 121 \\
\hline & $\operatorname{RAO} 31^{\circ}$ & 80 & 18 & 705 & 10,26 & 2,01 & 154 \\
\hline & LAO $42^{\circ}$ & 90 & 20 & 1112 & 10,86 & 3,35 & 163 \\
\hline & Total & & & 5490 & 69,17 & 15,34 & 1038 \\
\hline
\end{tabular}

Nilai tertinggi tingkat paparan radiasi di area setinggi mata ditunjukkan pada proyeksi LAO (Left Anterior Oblique) $42^{\circ}$ yaitu 3,35 $\mu \mathrm{Sv}$ dengan waktu radiasi selama 10,86 detik serta laju tingkat paparan radiasi sebesar $1112 \mu \mathrm{Sv} / \mathrm{h}$. Nilai terendah ditunjukkan pada proyeksi LAO (Left Anterior Oblique) $52^{\circ}$ - Caudal $29^{\circ}$ yaitu sebesar $1,32 \mu \mathrm{Sv}$ dengan waktu radiasi selama 8,06 detik serta laju tingkat paparan radiasi sebesar $589 \mu \mathrm{Sv} / \mathrm{h}$.
Tabel 3: Hasil Pengukuran dosis area setinggi mata dokter operator pada pasien B.

\begin{tabular}{|c|c|c|c|c|c|c|c|}
\hline \multirow[t]{2}{*}{ No } & \multirow[t]{2}{*}{$\begin{array}{l}\text { Proyeksi dan } \\
\text { sudut }\end{array}$} & \multicolumn{2}{|c|}{$\begin{array}{l}\text { Faktor } \\
\text { eksposi }\end{array}$} & $\begin{array}{c}\text { Laju } \\
\text { tingkat } \\
\text { paparan } \\
\text { radiasi } \\
\text { setinggi } \\
\text { mata } \\
\end{array}$ & Waktu & \multirow[t]{2}{*}{$\begin{array}{c}\text { Tingkat } \\
\text { paparan } \\
\text { radiasi di } \\
\text { area } \\
\text { setinggi } \\
\text { mata } \\
\mu \text { Sv }\end{array}$} & \multirow[t]{2}{*}{ Fram } \\
\hline & & $\mathrm{kV}$ & $\mathrm{mA}$ & $\mu S v h$ & Detik & & \\
\hline & $\operatorname{APCRA} 30^{\circ}$ & 90 & 19 & 2323 & 14,5 & 9,36 & 0 \\
\hline & $\mathrm{RA} 016^{\circ} \mathrm{CRA} 30^{\circ}$ & 80 & 14 & 259 & 6,86 & 0,49 & 103 \\
\hline & $\mathrm{RA0} 31^{\circ} \mathrm{CAU} 21^{\circ}$ & 80 & 14 & 136 & 5,3 & 0,20 & 80 \\
\hline & $\mathrm{LA} 030^{\circ} \mathrm{CRA} 20^{\circ}$ & 95 & 19 & 4002 & 6,27 & 6,97 & 94 \\
\hline & $\mathrm{LAO} 54^{\circ} \mathrm{CAU} 22^{\circ}$ & 120 & 14 & 3634 & 6 & 6,06 & 90 \\
\hline & RAO & - & - & - & . & . & - \\
\hline & $\mathrm{LAO} 48^{\circ}$ & 90 & 15 & 1047 & 7 & 2,04 & 105 \\
\hline & Total & & & 11400 & 46 & 25,11 & 472 \\
\hline
\end{tabular}

Pada Tabel 3. menunjukkan tingkat paparan radiasi di area setinggi mata yang terukur dengan menggunakan alat ukur survey meter pada pasien B dengan dokter operator Apada setiap proyeksi memberikan total laju tingkat paparan radiasi sebesar $11400 \mu \mathrm{Sv} / \mathrm{h}$ dengan dosis area setinggi mata diperoleh sebesar 25,11 $\mu \mathrm{Sv}$ selama 46 detik. Nilai tertinggi tingkat paparan radiasi area setinggi mata ditunjukkan pada proyeksi PA-Cranial $30^{\circ}$ yaitu 9,36 $\mu \mathrm{Sv}$ dengan waktu radiasi selama 14,5 detik serta laju dosis sebesar 2323 $\mu \mathrm{Sv} / \mathrm{h}$. Namun, pada Tabel 3 menunjukkan nilai laju tingkat paparan radiasi tertinggi pada proyeksi LAO (Left Anterior Oblique) 30 $30^{\circ}$ Cranial $20^{\circ}$ sebesar $4002 \mu \mathrm{Sv} / \mathrm{h}$. Nilai terendah tingkat paparan radiasi area setinggi mata ditunjukkan pada proyeksi RAO (Right Anterior Oblique) $31^{\circ}$ - Caudal $21^{\circ}$ yaitu sebesar 0,20 $\mu \mathrm{Sv}$ dengan waktu radiasi selama 5,3 detik serta laju tingkat paparan radiasi sebesar $136 \mu \mathrm{Sv} / \mathrm{h}$.

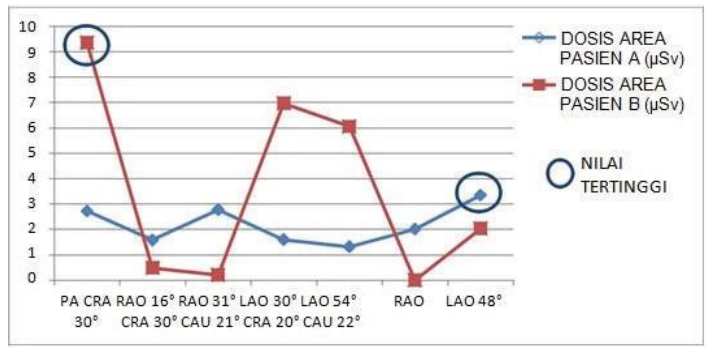

Gambar 3. Diagram tingkat paparan radiasi di area setinggi mata dokter operator pada setiap proyeksi untuk pasien $\mathrm{A}$ dan $\mathrm{B}$

Pada gambar 3 menunjukkan diagram tingkatpaparan radiasi di area setinggi mata dokter operator menununjukkan grafik pada pasien B mengalami lonjakan grafik yang sangat signifikan pada proyeksi PA - Cranial $30^{\circ}$. Sedangkan, grafik pada pasienAtidak mengalami lonjakan yang signifikan pada setiap proyeksinya dengan nilai tertinggi pada proyeksi LAO (Left Anterior Oblique) $48^{\circ}$. 


\section{Data Penunjang Pemeriksaan DiagnostikCoronary Angiography di Ruang Cathlab.}

Data penunjang pemeriksaan diagnostik coronary angiography diambil dalam waktu 1 bulan terakhir yaitu mulai bulan Mei sampai 13 Juni 2016 di Ruang Cathlab Instalasi Diagnostik dan Intervensi Kardiovaskuler (IDIK) RSUD dr. Soetomo Surabaya diperoleh 9 data pemeriksaan diagnostic coronary angiography dan 24 data pemeriksaan diagnostic coronary angiography dengan PTCA. Data tersebut berisi dosis selama pemeriksaan berlangsung dan total dosis yang diterima pasien. Data tersebut ditunjukkan pada Tabel 4. untuk tindakan khusus Diagnostic Coronary Angiography sebanyak 9pemeriksaan.

Diagram pada Gambar 4 menunjukkan bahwa pada pemeriksaan diagnostic coronary angiography dengan jumlah pasien pada dokter operator A adalah 7 pasien dan dokter operator B sebanyak 2 pasien menunjukkan total dosis, DAP (Dose Area Product) dan fluoroscopy time yang lebih tinggi dibandingkan dengan operator B.

Tabel 4: Data Total Fluoroscopy Time, Dose, dan DAP pada Pemeriksaan Diagnostic Coronary Angiography dengan operator A dan B untuk Bulan Mei hingga 13 Juni 2016.

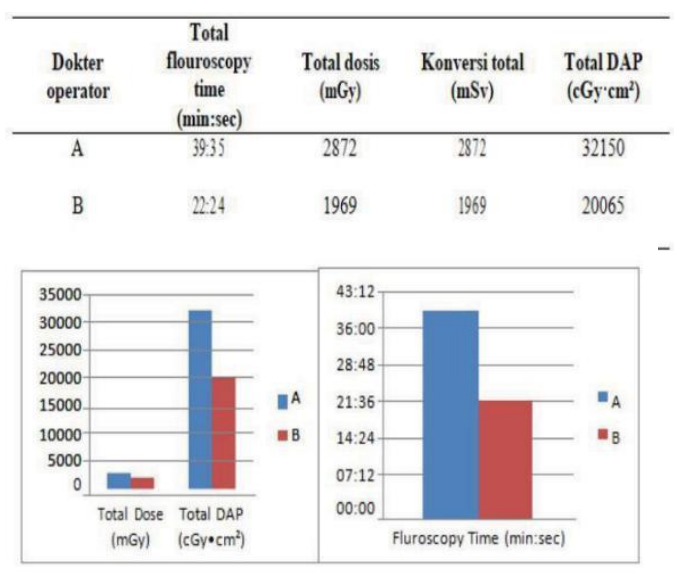

Gambar 4. Diagram Total Dose (mGy) dan DAP $\left(\mathrm{cGy} . \mathrm{cm}^{2}\right)$ serta Fluoroscopy Time (min:sec) pada pada

Pemeriksaan Diagnostic Coronary Angiography operator A dan B bulan Mei hingga 13 Juni 2016.

Canadian Nuclear Safety Comission (2015) mengatakan, "Ketika radiasi pengion menembus tubuh manusia atau suatu obyek, hal tersebut menyimpan energi yang diserap dari paparan radiasi disebut dosis. Kuantitas dosis radiasi dijelaskan dalam 3 macam yaitu dosis serap, dosis ekuivalen, dan dosis efektif." Tingkat paparan radiasi di area setinggi mata dokter operator termasuk dalam dosis ekuivalen.

Selama pemeriksaan diagnostic coronary angiography, penerimaan dosis radiasi dipengaruhi beberapa parameter yaitu faktor eksposi, sudut proyeksi, dan fluoroscopy time. Sudut proyeksi merupakan faktor yang mempengaruhi besar dosis yang diterima pada mata (Sandblom,2012).

Angulasi pada tabung juga dapat mempengaruhi dosis yang diterima pasien maupun pekerja radiasi. Pada pemeriksaan diagnostic coronary angiography memerlukan beberapa sudut proyeksi untuk melihat pembuluh darah jantung dengan baik.

Pada penelitian Terramoto dkk, 2008 dalam jurnal "Staff doses in Interventional Cardiology:Use of c-arm standard positions to assess incident dose rate" dilakukan pengukuran dalam dua metode yaitu metode pertama, pada setiap rotasi dan angulasi diukur pada satu titik, dan metode kedua, pada gabungan rotasi dan angulasi diukur pada dua titik yang berbeda. Pada kedua metode dilakukan pengukuran pada dua bagian tubuh yaitu mata dan alat kelamin (gonad) serta dua mode operasional yaitu fluoroskopi dan cine. Pada penelitian Terramoto ini digunakan phantom yang terbuat dari kayu berbentuk silinder dengan diameter $27 \mathrm{~cm}$ dan tinggi $31 \mathrm{~cm}$ serta factor koreksi 1,17. Alat ukur yang digunakan adalah TLD (Thermo Luminisence Dosemeter) seri N-80 dari ISO4047-1 dengan alat baca otomatis Harshaw 6600. Pada pengukuran dengan metode kedua, saat c-arm dengan $\mathrm{kV}$ antara 61-66 dan mA antara 128-160 didapatkan hasil pada Tabel 5. Dalam Tabel 6.1 menjelaskan bahwa penggunaan rotasi (+) yang dimaksud adalah LAO (Left Anterior Oblique) dan rotasi (-) adalah RAO (Right Anterior Oblique), sedangkan untuk angulasi (+) adalah cranial dan angulasi (-) adalahcaudal.

Tabel 5: Data ID rate menggunakan mode flouroskopi dalam tindakan kardiologi intervensi (Terramoto,2008).

\begin{tabular}{|c|c|c|c|c|}
\hline \multicolumn{5}{|c|}{ Table 5-ID rates in Fluoroscopic mode } \\
\hline & \multicolumn{2}{|c|}{ Site 1} & \multicolumn{2}{|c|}{ Site 2} \\
\hline $\begin{array}{l}\text { Rotation/Angulation } \\
\text { (\%) }\end{array}$ & $\begin{array}{l}\mathrm{ID}_{\text {(masus rate }} \\
(\mu \mathrm{Gy} / \mathrm{min})\end{array}$ & $\begin{array}{l}\mathrm{D}_{\text {eve rate }} \text { rate } \\
(\mu \mathrm{Gy} / \mathrm{min})\end{array}$ & $\begin{array}{l}\mathrm{ID}_{(\mu \mathrm{mas}, \mathrm{rate}} \\
(\mu \mathrm{G} / \mathrm{min})\end{array}$ & $\begin{array}{l}\mathrm{ID}_{\mathrm{ese}} \text { rate } \\
(\mu \mathrm{Gy} / \mathrm{min})\end{array}$ \\
\hline R0 A-30 & 6.92 & 6.05 & 13.44 & 9.60 \\
\hline R 45 A. 25 & 7.35 & 3.68 & 11.52 & 7.68 \\
\hline$R-20 A-20$ & 5.19 & 3.68 & 9.60 & 3.84 \\
\hline R. $30 \mathrm{~A} 0$ & 3.46 & 2.81 & 7.68 & 5.76 \\
\hline ROAO & 4.32 & 3.68 & 11.52 & 5.76 \\
\hline $\mathrm{R} 30 \mathrm{~A} 0$ & 6.70 & 3.46 & $\begin{array}{l}15.36 \\
\end{array}$ & 7.68 \\
\hline R90 A0 & 0.00 & 3,46 & 7.68 & 5.76 \\
\hline R30 A25 & 10.81 & 5.84 & 34.56 & 11.52 \\
\hline $\mathrm{R}-20 \mathrm{~A} 30$ & 5.19 & 3.89 & 17.28 & 9.60 \\
\hline R0 A 30 & 8.22 & 5.84 & 2688 & 11.52 \\
\hline
\end{tabular}


Pada penelitian ini, pengukuran dosis area setinggi mata dokter operator dilakukan pada satu titik yang berada pada jarak $80 \mathrm{~cm}$ dari tube sinar-X dan terletak setinggi mata dokter operator yaitu 150 $\mathrm{cm}$ dari lantai. Pengukuran tingkat paparan radiasi ini dilakukan secara langsung menggunakan survey meter Thermo Scientific seri FH 40 G-L. Pada hasil pengukuran didapatkan nilai terendah pada pasien A ditunjukkan proyeksi LAO (Left Anterior Oblique) $52^{\circ}$ - Caudal $29^{\circ}$ sebesar $1,32 \mu \mathrm{Sv}$ dengan waktu radiasi selama 8,06 detik serta laju tingkat paparan radiasi sebesar $589 \mu \mathrm{Sv} / \mathrm{h}(9,82 \mu \mathrm{Sv} / \mathrm{min})$ dan pasien B proyeksi RAO (Right Anterior Oblique) $31^{\circ}$ Caudal $21^{\circ}$ sebesar $0,20 \mu \mathrm{Sv}$ dengan waktu radiasi selama 5,3 detik serta laju tingkat paparan radiasi sebesar $136 \mu \mathrm{Sv} / \mathrm{h}(2,27 \mu \mathrm{Sv} / \mathrm{min})$. Hal ini juga didukung oleh penelitian Terramoto, pada Tabel 6.1 ditunjukkan pada rotasi $45^{\circ}$ dan angulasi $-25^{\circ}$ (LAO $45^{\circ}$ - Caudal $25^{\circ}$ ) pada pengukuran titik kedua di bagian mata didapatkan laju dosis serap sebesar 7,68 $\mu \mathrm{Gy} / \mathrm{min}(7,68 \mu \mathrm{Sv} / \mathrm{min})$, sedangkan pada rotasi $20^{\circ}$ dan angulasi $-20^{\circ}$ (RAO 20 -Caudal $20^{\circ}$ ) diperoleh pengukuran sebesar $3,84 \mu \mathrm{Gy} / \mathrm{min}(3,84$ $\mu \mathrm{Sv} / \mathrm{min})$. Pada kedua hasil penelitian tersebut menunjukkan bahwa pada proyeksi LAO-Caudal dan RAO-Caudal memberikan radiasi yang cukup rendah dalam penggunaannya selama pemeriksaan diagnostic coronary angiography. Selain itu, peneliti lain juga mengatakan pada proyeksi dengan sudut rotasi mendekati dokter operator lebih rendah dibandingkan dengan sudut rotasi yang menjauhi dokter operator, dengan penggunaan rotasi dan angulasi pada suduttertentu.

Nilai tertinggi pada pengukuran menggunakan survey meter pada pasien A proyeksi LAO (Left Anterior Oblique) $42^{\circ}$ yaitu $3,35 \mu \mathrm{Sv}$ dengan waktu radiasi selama 10,86 detik serta laju tingkat paparan radiasi sebesar $1112 \mu \mathrm{Sv} / \mathrm{h}(18,53 \mu \mathrm{Sv} / \mathrm{min})$ dan pasien B proyeksi PA - Cranial $30^{\circ}$ yaitu $9,36 \mu \mathrm{Sv}$ dengan waktu radiasi selama 14,5 detik serta laju tingkat paparan radiasi sebesar $2323 \mu \mathrm{Sv} / \mathrm{h}$ $(38,72 \mu \mathrm{Sv} / \mathrm{min})$. Pada Tabel 6.1 untuk rotasi $30^{\circ}$ dan angulasi $0^{\circ}\left(\mathrm{LAO} 30^{\circ}\right)$ didapatkan pengukuran pada titik kedua di bagian mata dengan laju dosis serap sebesar 7,68 $\mu \mathrm{Gy} / \mathrm{min}(7,68 \mu \mathrm{Sv} / \mathrm{min})$, sedangkan rotasi $0^{\circ}$ dan angulasi $30^{\circ}$ (PA-Cranial $30^{\circ}$ ) menunjukkan laju dosis serap sebesar 11,52 $\mu \mathrm{Gy} / \mathrm{min}$ (11,52 $\mu \mathrm{Sv} / \mathrm{min})$. Pada kedua penelitian untuk proyeksi PA-cranial menunjukkan nilai laju tingkat paparan radiasi yang cukup tinggi namun pada proyeksi LAO tidak terlalu tinggi. Hal ini bisa disebabkan oleh faktor parameter lain yaitu lama fluoroskopi.

Berdasarkan PERKA BAPETEN Nomor 8 Tahun 2011 pasal 30 ayat (3) huruf a, menyatakan bahwa Nilai Batas Dosis untuk Pekerja Radiasi pada dosis ekivalen untuk lensa mata sebesar $150 \mathrm{mSv}$ (seratus limapuluh milisievert) dalam 1 (satu) tahun. Selain itu, pada PERKA BAPETEN Nomor 4 Tahun 2013 Pasal 15 menyatakan bahwa Nilai Batas Dosis untuk Pekerja Radiasi sebagaimana dimaksud dalam Pasal 14 huruf a ditetapkan dengan ketentuan dosis ekivalen untuk lensa mata rata-rata sebesar $20 \mathrm{mSv}$ (dua puluhmilisievert) per tahun dalam periode 5 (lima) tahun dan $50 \mathrm{mSv}$ (limapuluh milisievert) dalam 1 (satu) tahun tertentu.

Jika Nilai Batas Dosis (NBD) untuk lensa mata dalam satu tahun tidak melampaui $150 \mathrm{mSv}$, dalam satu tahun ada 50 minggu maka dosis ekivalen yang diterima pada lensa mata sebesar $3 \mathrm{mSv} /$ minggu. Pada pekerja dengan beban kerja 8 jam per hari dan 5 hari dalam satu minggu, maka dosis ekivalen pada lensa mata sebesar $0,075 \mathrm{mSv} / \mathrm{jam}$ setara dengan $75 \mu \mathrm{Sv} / \mathrm{jam}$

Pada akumulasi data pengukuran dosis area setinggi mata dokter operator atas dua pasien dengan operator berbeda menunjukkan total tingkat paparan radiasi di area setinggi mata pada pasien $\mathrm{A}$ sebesar $15,34 \mu \mathrm{Sv}$ selama 1 menit 9,17 detik dan pasien B sebesar 25,11 $\mu$ Sv selama 46 detik. Jika Nilai Batas Dosis (NBD) yang ditentukan oleh PERKA BAPETEN untuk lensa mata dalam satu jam tidak boleh melampaui dosis ekivalen sebesar $75 \mu \mathrm{Sv}$, maka hasil pengukuran dosis area setinggi mata pada pasien A dan B tidak melebihi dan masih tergolong jauh lebih rendah dari Nilai Batas Dosis yang telah ditentukan.

Pada data penunjang pemeriksaan yang dilakukan mulai bulan Mei hingga 13 Juni 2016 diperoleh data pemeriksaan diagnostic coronary angiography sejumlah 9 pada 2 dokter operator, dokter operator A sebanyak 7 pasien dan operator B sebanyak 2 pasien. Waktu tercepat yang tercatatpada data penunjang untuk diagnostic coronary angiography diperoleh selama 1 menit 39 detik. Namun, pada hasil penelitian untuk pasien A dan B yang dilakukan diagnostic coronary angiography memerlukan waktu yang lebih cepat dibandingkan dengan waktu pemeriksaan yang tercatat pada data penunjang yaitu berturut-turut 1 menit 9,17 detik dan 46detik.

Pada hasil analisis diatas, pengukuran tingkat paparan radiasi di area setinggi mata dokter operator selama pemeriksaan

diagnosticcoronary angiography menunjukkan tingkat paparan radiasi yang tidak melebihi Nilai Batas Dosis (NBD) yang ditentukan pada lensa mata. Lamanya waktu fluoroskopi dan perolehan tingkat paparan radiasi yang berbeda-beda dipengaruhi oleh beberapa faktor parameter salah satunya yaitu penggunaan variasi proyeksi selama pemeriksaan. Selain itu, selama pengamatan dilakukan, dokter operator beserta timnya selalu memperhatikan penggunaan alat proteksi diri berupa apron, pelindung thyroid, kacamata $\mathrm{Pb}$, dan kaca tabir telah sering digunakan oleh dokter operator selama melakukan pemeriksaan diagnostic coronary angiography di Ruang Cathlab Instalasi Diagnostik dan Intervensi Kardiovaskuler RSUD Dr.SoetomoSurabaya.

Diharapkan selama melakukan pemeriksaan diagnostic coronary angiography, dokter operator beserta tim yang berada di dalam ruang cathlab dipastikan selalu menggunakan perlengkapan 
proteksi diri meliputi apron, pelindung thyroid, terutama kacamata $\mathrm{Pb}$ untuk menghindari efek deterministik pada lensa mata. Adapun cara lain untuk mengurangi dosis meliputi, merubah mode fluoroskopi dari continuous ke pulse, mengurangi penggunaan frame pada cine dari 30 frames $/ \mathrm{sec}$ menjadi 7,5/15 frame/sec, menggunakan kolimasi yang secukupnya, dan mengurangi penggunaan magnifikasi. Selain itu, dokter operator mengurangi fluoroscopy time pada proyeksi yang memberikan tingkat paparan radiasi tinggi seperti proyeksi LAO (Left Anterior Oblique) $42^{\circ}$ dan proyeksi LAO (Left Anterior Oblique) $30^{\circ}$-Cranial $20^{\circ}$.

\section{Simpulan}

Tinggi tingkat paparan radiasi di area setinggi mata dokter operator selama pemeriksaan diagnostic coronary angiography di Ruang cathlab Instalasi Diagnostik dan Intervensi Kardiovaskuler RSUD Dr.Soetomo Surabaya pada pengukuran menunjukkan untuk pasien A memberikan kontribusi tingkat paparan radiasi di area setinggi mata dokter operator sebesar $15,34 \mu \mathrm{Sv}$ selama 69,17 detik (1 menit 9,17 detik) dan pada pasien B sebesar 25,11 $\mu \mathrm{Sv}$ selama 46 detik. Tingkat paparan radiasi di area setinggi mata dokter operator selama pemeriksaan diagnostic coronary angiography pada pasien A dan B di Ruang cathlab Instalasi Diagnostik dan Intervensi Kardiovaskuler RSUD Dr.Soetomo Surabaya tidak melebihi dan jauh lebih rendah dari Nilai Batas Dosis (NBD) yang ditentukan pada lensa mata sebesar $75 \mu \mathrm{Sv} / \mathrm{jam}$. Selama pengamatan, dokter operator beserta tim selalu memperhatikan penggunaan alat proteksi diri berupa apron, pelindung thyroid, kacamata $\mathrm{Pb}$, dan kaca tabir yang lengkap selama pemeriksaan diagnostic coronary angiography berlangsung.

\section{Daftar Pustaka}

IAEA. 2009. ESTABLISHING GUIDANCE LEVELS IN $X$ RAY GUIDED MEDICAL INTERVENTIONAL PROCEDURES: APILOT STUDY. Safety Report Series, 59.

BAPETEN 2011. PERKA BAPETEN tentang Keselamatan Radiasi dalam Penggunaan Pesawat Sinar-X Radiologi Diagnostik dan Intervensional. Jakarta: BAPETEN
BAPETEN 2013. PERKA BAPETEN tentang Proteksi dan Keselamatan Radiasi dalam Pemanfaatan Tenaga Nuklir. Jakarta: BAPETEN.

BATAN. Alat Ukur Radiasi [Online]. BATAN. [Accessed March, 28 2016].

BATAN 2011. Pedoman Keselamatan dan Proteksi Radiasi Kawasan Nuklir Serpong.Serpong: BATAN.

Commission, C. N. S. 2015. Radiation Dose [Online]. Canada: Canadian Nucles Safety Commission. [Accessed March, 20 2016].

Renato, P. 2006. RE: Dose Levels in Digital $\begin{array}{ll}\text { Radiology Keith } & \text { Faulkner. } \\ \text { RSUA2015.Prosedur } & \text { Pemeriksaan } \\ \text { Cathlab. Surabaya:RSUA. } & \end{array}$

Sandblom, V. 2012. Evaluation of Eye LensDoses Received by Medical StafWorking.

Terramoto L, Matoso, L. , Olivera A. D.,Leite E., 2008. Staff doses in Interventional Cardiology: Use of c-arm standard positions to assess incident dose rate. Available:

ttps://www.researchgate.net/publication/234 022757. 